William Hansen. Ariadne's Thread: A Guide to International Tales Found in Classical Literature. Ithaca and London: Cornell University Press, 2001. 548 pp. \$45.00. Index, bibliography. ISBN 0-8014-3670-2.

When Theseus went into the labyrinth to face the Minotaur, he had something no other youth had had before him: Ariadne's thread. The beautiful Ariadne, daughter of King Minos of Crete, fell in love with Theseus as he waited to be sacrificed and offered her help. She gave him a thread to unravel as he walked into the depth of the labyrinth and, using Ariadne's thread, Theseus was able to find his way back out once he had slain the Minotaur. Like Ariadne's thread, Hansen's book guides us through the labyrinth of story. His stated purpose is to take Classical, meaning Greek and Roman, narratives and to discuss their relationship to international tale types and motifs. Thus, the story of Theseus and the Minotaur is linked to the widely known and popular folktale The Girl as Helper in the Hero's Flight, AT 313C. In the oral version, a woman, usually the daughter of a witch or ogre, falls in love with the hero and promises to help him on the condition that he marry her. After fulfilling various tasks assigned to the hero by her parent, the girl helps him escape by using her magic, turning herself into a well and the hero into a bucket, or casting her comb behind her, at which point it turns into a dense forest. The magic tricks of the girl successfully deter her parent, but the witch or ogre casts a spell so that the hero will forget the girl. Usually, the spell takes effect only if the hero performs some action, such as kissing a relative upon his return. The girl warns him not to do so, but he forgets or disobeys, at which point he becomes oblivious to his rescuer and his promise to her and almost marries another. In most tales, though not in the story of Ariadne, the girl manages to disenchant the hero and restore his memory at the last moment. The two are then reunited and live happily ever after.

When discussing the connection between Girl as Helper and Ariadne, Hansen gives the folk versions of this story, their variations, and a bibliography showing where published texts may be found. He discusses the relationship of the folk narratives to Classical literature; in this case, Theseus and Ariadne is but one of three stories that he analyses. Finally, he provides copious and wonderfully detailed notes. And Girl as Helper is but one of the almost one hundred tale types treated by Hansen, each of which he covers with equal thoroughness and with 
exemplary sensitivity. Truly, this is a monumental work, an encyclopedic compendium of information.

While the discussion of international folktales and their realization in Classical literature is the heart of Hansen's work, he offers us additional services of great value. His introduction covers the history of folktale scholarship clearly, succinctly, and in eminently readable form. Hansen explains the Aarne-Thompson Tale-Type Index with equal skill. The bibliography at the end of the book is a treasure trove.

Perhaps most interesting are Hansen's speculations on the relationships between narrative genres. The Aarne-Thompson Tale Type Index was developed to catalogue folktales and thus we associate the international plots that Hansen discusses with folktales in general, and fairy or magic tales in particular. These are stories that are admittedly fantastic. They take place "once upon a time" in a kingdom "three times nine kingdoms away." Their actors have names that are generic (Jack, Hans, Ivan) or descriptive (Goldilocks, Cinderella, Beauty). The Classical stories that have related plots and motifs are not magic tales at all, but belong to the category of legend: they are tied to a specific time and place and the actors in them are people who supposedly really lived. Thus, in the narrative of Ariadne/Girl Helper, the international version takes place in an unspecified time and place and the girl is known simply as the witch's or ogre's daughter, while in the Greek narrative, the story takes place in Crete, the girl is Ariadne, the daughter of Minos, and so forth. The usual supposition has been that stories of the legend variety, the ones based on fact or alleged fact, were the originals and that fantastic tales recorded in the Early Modern period were a later development, an evolution of Classical, "factual" tales. The reasoning behind this supposition was the assumption that the human narrative process does not make a story ex nihilo, but starts with a description of a real event which, with time, is forgotten, allowing the narrative to acquire more general and often fantastic attributes. Bolstering this line of thought was the fact that Classical literature predates recordings of oral folktales. Hansen states that his work in Classical literature has convinced him that the more general magic tales are the "original" stories and that the Greek and Roman legends are concretizations of them. And, of course, his entire book shows us in detail how legends and magic tales are related, how, if we take into account the differing characteristics of legend and tale, these two genres can be seen to share the same tale types.

Hansen's work has important implications for contemporary narrative scholarship. In Ukraine, where I work, as in most other countries within the continuum covered by the AT Index, 
the people who tell magic tales are few. This situation is usually taken to indicate that oral traditional literature is dying, destroyed by television and other mass media. In the same geographical area, legends abound, but are often dismissed. They are not taken seriously because they are seen as expressions of superstition rather than as art, no matter how long, complex, and well-told they may be. Legend plots, as Hansen teaches us, are related to tale types. For example, what I have encountered as true accounts of the return of the dead to instruct the living to stop grieving is also AT 769. As Hansen also points out, certain genres carry prestige at certain times. Folktales were once disparaged as lesser literature, if they were considered literature at all. Perhaps we should not be so ready to dismiss contemporary legends but should look at their relationship to magic tales, as Hansen does for Classical literature.

Moreover, perhaps we should recognize that magic tales, fantastic though they may be, are not entirely art for art's sake, but are as bound to their time and place as legends. Guided by Ariadne's Thread, I can now see that a lovely folktale about a snake husband, which I encountered in my fieldwork only once, is related to commonly told legends about conflicts between mothers and daughters. What Hansen's work teaches us is that, even though the Snake Husband is a folktale and thus one of the few items of its genre still told orally, it should not be seen as an oddity but as one manifestation of a variety of narratives on an important real-life issue.

Hansen has produced a monumental work. He has dealt with an enormous volume of material his study is a wonderful reference tool. More importantly, he has compared stories that are usually considered distinct. Classical literature is often associated with high art and folklore with low. Magic tales are usually distinguished from true stories rather than linked to them. Hansen's work reveals connections where distinctions are normally made. As Ariadne's thread led Theseus out of the labyrinth, so Hansen's offers to lead us out of the potential trap of old conceptions of narrative.

\section{Natalie Kononenko}

University of Virginia 